\title{
Empowering educators with knowledge management for the development of state-of-art of the curriculum
}

\author{
Parul Dharmani Agarwal ${ }^{1 *}$, Ravi Kiran ${ }^{2}$ and Anil Kumar Verma ${ }^{3}$ \\ ${ }^{1}$ Department of Computer Science, Global Institute of Information and Technology, Greater Noida, U. P., India. \\ ${ }^{2}$ School of Management and Social Sciences, Thapar University, Patiala, Punjab, India. \\ ${ }^{3}$ Department of Computer Science and Engineering, Thapar University, Patiala, Punjab, India.
}

Accepted 12 December, 2011

\begin{abstract}
One of the main aims of any Institute of Higher Technical Education (IHTE) is to impart knowledge to the students in the most effective way, meet the needs of the students more efficiently and improve educational outcomes for the students. To remain ahead of competition, even well established IHTEs have to respond to the challenge by offering learners a dynamic and industry oriented curriculum. To achieve this objective, there is a need to facilitate academia with knowledge management (KM) based platform which can help them design innovative, industry oriented and state-of-art curriculum which has been accomplished in this paper. A structured questionnaire was designed to investigate the factors for the inclusion in curriculum development portal and its perceived benefits. On the basis of the data and personal interviews, a KM based curriculum development portal design is proposed which can be leveraged by IHTEs to enhance their curriculum development and thereby breed industry oriented professionals. It may also be used to create a blueprint-for developing a knowledge management portal for higher educational institutions.
\end{abstract}

Key words: Knowledge management, higher education, curriculum development, portal, educational technology.

\section{INTRODUCTION}

It is well said by Drucker (1993) that "we are entering the knowledge society in which the basic economic resource...is knowledge... and where the knowledge worker will play a central role". We have moved from scarcity of information to its abundance due to information and communication technology, internet, television etc. The researchers do not have a consensus regarding defining knowledge and knowledge management (KM), but all schools of thought agree in presuming that knowledge is different from information and data. The literature of knowledge management is scattered and varied, ranging from volumes of short notes on practice to articles on knowledge management topics in journals not exclusively devoted to knowledge management to a

*Corresponding author. E-mail: paruldagarwal@yahoo.co.in. Tel: +919717120027. handful of scholarly journals dedicated to knowledge management (Wallacea et al., 2011). Many researchers accept that knowledge is the only meaningful economic resource in the knowledge society (Foray and Lundvall, 1996; Johnston and Rolf, 1998). According to Snowden (1999) defining knowledge is not necessary, but it is essentially important to distinguish it from information. Bohn (1994) distinguishing knowledge from information and data expresses that knowledge is something that prescribes what to do, while information is the structured data and data is raw material. Kogut and Zander (1992) define information as factual statement and knowledge as a statement of how to do. Knowledge represents a pattern that connects and generally provides a high level of predictability (Bateson, 1988). In the views of Davenport et al. (1999) knowledge is information combined with experience, context, interpretation, and reflection. Prusak (1999) regards knowledge as a human trait and distinguishing it from information as only a human 


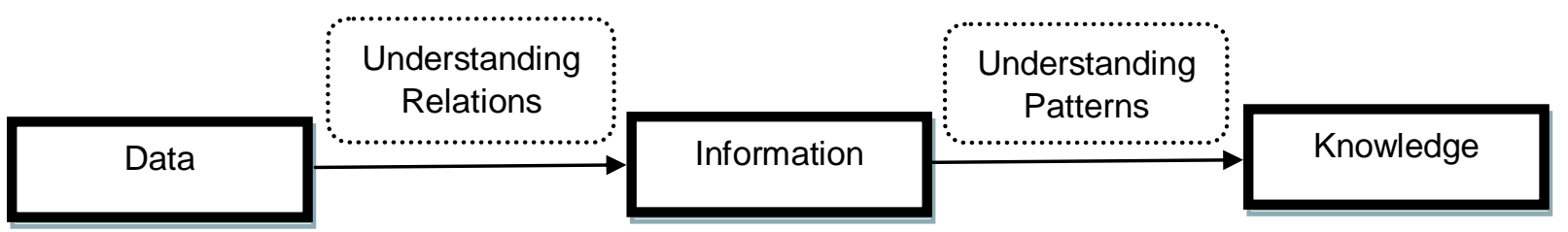

Figure 1. Relationship between data, information and knowledge.

can obtain knowledge. Knowledge is broadly defined as information combined with experience, context, interpretation and reflection, is a high value form of information that is ready to business process, decisions and actions. Knowledge refers to the sum of what is known: A familiarity, awareness or understanding gained through experience that, in a business context, guides operations and administrative processes (Coukos and Eleni, 2003). Davenport and Prusak (1998) opine that knowledge originates and is applied in the minds of knower. In organizations, it often becomes embedded not only in documents or repositories but also in organizational routines, processes, practices and norms.

In short, knowledge is a gradual transformation from data to information after understanding relations and when patterns are understood information transforms into knowledge as shown in Figure 1.

People attain knowledge while performing specific tasks, taking decisions in crucial situations and solving the problems. The new knowledge resides in their minds, but that has not been documented in a structured manner leading to its loss most of the time.

Knowledge management $(\mathrm{KM})$ is generally about the gathering, storing, disseminating and application of knowledge via the know-how and creation of work by the individuals in an organization (Miller, 1999). Many of the world's most successful corporations, businesses and organizations are investing considerable resources on KM (Alvesson and Karreman, 2001). KM principles recognize that it is important for organizations to "know what they know". Knowledge management involves the panoply of procedures and techniques used to get the most from an organization's tacit and codified know-how (Teece, 2000). While defined in many different ways, knowledge management generally refers to how organizations create, retain and share knowledge (Argote and Ingram, 2000; Huber, 1991). All institutions inherently store, access and deliver knowledge in some manner. Like water, this rising tide of data can be viewed as an abundant, vital and necessary resource. With enough preparation, we should be able to tap into that reservoir -and ride the wave -- by utilizing new ways to channel raw data into meaningful information. That information, in turn, can then become the knowledge that leads to wisdom (Alberthal, 1995).

According to Wiig et al. (1997), people and organizations practice knowledge management to achieve two main objectives. The first is to make the enterprise act as intelligently as possible to secure its viability and overall success. The second objective is to gain understanding of the best value of knowledge assets. Wiig (2000) asserts that knowledge management serves to foster and promote intelligent behaviours. Skyrme and Amidon (1997) opine that any knowledge management project requires a systematic and holistic view of the knowledge agenda.

Most business actions require the guidance of both explicit and tacit knowledge (Kidwell et al., 2000). These master craftsmen have years of experience and therefore also a wealth of expertise. Nevertheless, they often have difficulty in articulating the technical and scientific principles behind what they know. Colleges and universities move closer to private-sector behaviours and values as described by academic capitalism theory (Slaughter and Leslie, 1997; Slaughter and Rhoades, 2004), opportunities for the influx of business strategies into higher education institutions increase.

\section{Knowledge management in higher education}

It is important for organizations to "know what they know" and make maximum use of their knowledge. The problem today is not how to find knowledge, but how to manage it. Being the powerhouse of knowledge in our society, universities and other higher educational institutions have immense knowledge. There are hidden, untapped reservoirs of intelligence that exist in almost every organization. There is a difference in ranking in two universities with identical numbers of faculty, degree programs, expenditures and enrollment as those surveys conducted by U.S. News and World Report. (Milam, 2001) suggests that the difference is often intangible value that is added by effective knowledge management.

According to Petrides and Nodine (2003), educational institutions, however, seem to be working in a more complex way, as these organizations are adaptive and are social systems where people co-operate with technologies to evolve processes to achieve common goals. Just as ecosystems rejuvenate themselves through cycles and seasons, educational organizations grow and revitalize themselves through the knowledge they create, their processes facilitate passing that knowledge on to others and the exchanges and relationships that they 


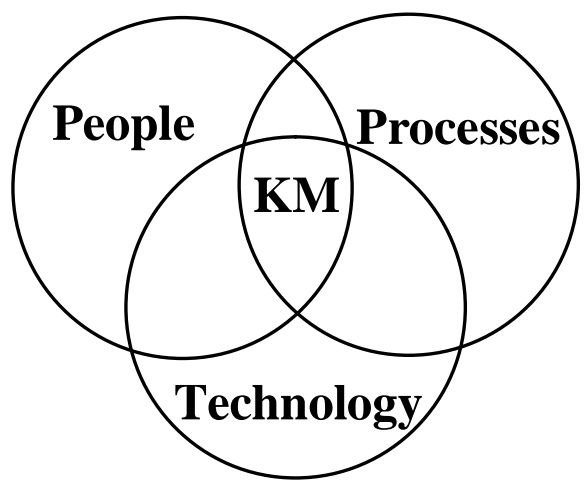

Petrides et al. (2003)

Figure 2. Key realms of knowledge management.

foster among people. Knowledge management therefore, very aptly brings together three core organizational resources: people, processes and technologies, to enable the educational institutions use and share information most optimally and effectively (Figure 2). KM in education can therefore be thought of as a framework or an approach that enables people within the institution to develop a set of practices to collect information and share what they know leading to actions that improve services and outcomes (Petrides and Nodine, 2003).

Although, there has been a great deal of recognition in business world that information and knowledge management can be vital tools in organizations, now the educational administrators and teachers have begun to look at how they might use knowledge management to assist in creating effective learning environment. Higher education institutions have "significant opportunities to apply knowledge management practices to support every part of their mission," explains Kidwell et al. (2000).

Being the powerhouse of knowledge in our society, universities and other higher educational institutions have immense knowledge. There are hidden, untapped reservoirs of intelligence that exist in almost every organization. There is a difference in ranking in two universities with identical numbers of faculty, degree programs, expenditures and enrolment as those surveys conducted by U.S. News and World Report. Milam (2001) suggests that the difference is often intangible value that is added by effective knowledge management.

\section{Knowledge management and curriculum development process}

Curriculum development is the process whereby values are interpreted and arranged into learning experiences (Wiles and Bondi, 2006). Richards (2001) describes curriculum development as "the range of planning and implementation processes involved in developing or renewing a curriculum". The researcher defines the processes as focusing on "needs analysis, situational analysis, planning learning outcomes, course organization, selecting and preparing teaching materials, providing for effective teaching and evaluation". Institutions being people driven usually develop their curriculum based on the perception of their expert faculty, who often do not possess the first hand information about the industry and the market needs, as a result the curriculum produces human power whose relevance as well as quality becomes often unacceptable to the industries and organizations who outsource their manpower needs from universities and institutions. In the Indian context, this has become a major concern being voiced by the industries and industry association (Sharma, 2007). For most individuals, integrating and managing knowledge and information in a systematic way is a challenge. In the demanding professional world, one must learn to manage oneself and his/her formal and informal exchanges and interactions with others. It is always considered that two heads are better than one head. Efficient knowledge management needs not only to document knowledge, but also to provide tools for collaboration among all contributors to the knowledge pool. Knowledge management helps an organisation gain insight and understanding from its own experiences.

When employees use knowledge management system, best practices are stored throughout the organization and each employee accessing the system has power similar to the best employee (Markus, 2002). The need for universities to make better use of their information assets was stressed in the National Committee of Inquiry into Higher Education, which called for the development of communications and information strategies in every university in UK by the turn of the millennium (McManus and Loughridge, 2002). Education portals create a common gateway to the data, information and knowledge that the people throughout the higher educational institutions need to effectively share information and work together on projects.

\section{Objective and hypotheses}

The objective of the present research is to propose a knowledge management (KM) based portal to improvise curriculum development in Institutions of Higher Technical Education (IHTE) with a view to reaping maximum benefits of existing knowledge in the IHTE to achieve state-of-art curriculum. The following hypotheses have been framed:

$\mathrm{H}_{1}$ : There is no significant difference in the rating given to factors for the inclusion in the KM portal for curriculum development by group A (senior management and senior academia) and group B (junior academia and research scholars). 
Table 1. Respondent's profile.

\begin{tabular}{lc}
\hline Designation & Number \\
\hline Group A: Senior mgmt and senior academia & 41 \\
Group B: Junior academia and research scholar & 100 \\
\hline
\end{tabular}

$\mathrm{H}_{2}$ : Perceived benefits that emerge from KM portal for curriculum development may be positively related with curriculum design and improvisation.

$\mathrm{H}_{3}$ : Perceived benefits that emerge from KM portal for curriculum development may be positively related with faculty development and knowledge bank.

$\mathrm{H}_{4}$ : Perceived benefits that emerge from KM portal for curriculum development may be positively related with corporate feedback, assessment techniques and lessons learned.

\section{DESIGN AND METHODOLOGY}

The factors for the inclusion in the knowledge management portal for curriculum development in the institutions of higher educational institutions (IHTE) had been investigated - an area that has, to date, received very little attention in the literature. Secondly, the present research tried to identify the perceived benefits of $\mathrm{KM}$ implementation in higher education. A questionnaire has been used to find out which factors are most relevant in for inclusion in the $\mathrm{KM}$ system according to academia. The instrument was repeatedly checked and appropriate alterations were made before it was finalized. Its reliability and validity is discussed later in the paper. A structured questionnaire was designed to gather data and also personal interviews were also conducted. This was selected for the following reasons (Chauvel and Despres, 2002):

(a) A survey brings an issue into focus by defining and specifying its various elements.

(b) Its results are typically quantifiable and thus amenable to statistical analysis.

(c) Statistical treatment allows the results obtained from a sample to be extended to a larger population, thus enabling the generation of more global statements.

(d) It is faster and more direct compared to many other research methods.

The following factors and perceived benefits are investigated using questionnaire to find out whether the Indian academia also believed that KM interventions could be applied to Indian Higher Education Institutions for their benefit.

\section{Knowledge management (KM) system factors}

The present research investigates the following eight factors for the inclusion in framework KM portal curriculum development.

1. Curriculum revision efforts that include lesson plan, content sequencing, reference of contents and so forth.

2. Assessment techniques, including best practices, outcomes tracking, faculty development opportunities and research.

3. Information related to teaching and learning with technology including faculty development opportunities, outcomes tracking, technology overviews, and so forth.
4. Analyzed student evaluations updated each semester for lessons learned and best practices for all faculty.

5. Information in each disciplinary area, including updated materials, recent publications, applicable research, and so forth.

6. New faculty with guides for developing curriculum, working with senior faculty, establishing effective teaching styles, advising do's and do not's, supervising PhD students and so forth.

7. Content modularized and arranged to facilitate interdisciplinary curriculum design and development.

8. Corporate relationships to identify curriculum design advisory task forces, guest speakers, adjuncts, case study sites and so forth.

An effort was made to cover selected top Institutions in Engineering and Management from all over India chosen from the best ranked institutions as given by Survey conducted by AC Nelson in India Today (2010). Statistical tools have been used to analyse the data through SPSS 17. The results of this analysis have formed the input for the design of a curriculum portal. The survey instrument investigates the factors for the inclusion in the knowledge management portal for curriculum development in the institutions of higher educational institutions (IHTE) - an area that has, to date, received very little attention in the literature. Secondly, to identify the perceived benefits of KM implementation in higher education. From the identified list of measurement factors, respondents were asked to rank their opinion about these issues using a 5-point Likert scale for each of the issues. The mean values for the usages were calculated on the following from highest to lowest with 5 being the highest and 1 being the lowest. After performing the interviews, all data so collected was analyzed and the portal framework has been designed.

Designations of the targeted respondents in the IHTEs were categorized into two groups. The first group consists of management, senior academia that is, Professors, Associate Professors which would be addressed as group A in the paper. These were considered to be the best addressees because they are the overseers of their institutions' operations and are likely to be the "thought" leaders of KM. While it is possible to argue that questionnaires should be forwarded to the CKO, the knowledge manager or the like, such positions are still not common in practice (Jarrar, 2002). The second group consists of Assistant Professors, Lecturers and Research Scholars who will be using and also contributing to the KM system would be addressed as group B.

\section{Profile of respondents}

Finally, questionnaires together with covering letters explaining the purpose of the survey were distributed to a total of 75 IHTEs in India through postal, email and personally. An effort was made to cover selected top Institutions in Engineering and Management from all over India, chosen from the best ranked institutions as given by Survey conducted by AC Nelson in India Today. Follow-up reminders were sent to improve the response rate. The details of the respondents are shown in Table 1. In total 141 responses were received from 30 institutions of higher education, out of which 41 were from group $A$ and rest 100 belong to group $B$.

\section{Reliability}

The internal reliability of the instrument was assessed using Cronbach's alpha, and content was validated by a panel of experts. A sample of 141 respondents representing 30 IHTE's yielded coefficients ranging from 0.883 to 0.903 as shown in Table 2 . According to Nunally (1978) the generally accepted standard for reliability estimates are values greater than 0.70 . The high reliability has been observed and this implies that the items do measure the same construct satisfactorily. The overall estimated item-wise 
Table 2. Item wise reliability.

\begin{tabular}{llcc}
\hline S. no. & Factor & $\begin{array}{c}\text { No. of } \\
\text { items }\end{array}$ & $\begin{array}{c}\text { Cronbach } \\
\text { alpha }\end{array}$ \\
\hline 1. & Knowledge management and curriculum development factors & 8 & 0.883 \\
2. & Perceived benefits and knowledge management & 8 & 0.903 \\
3. & Total & 16 & 0.929 \\
\hline
\end{tabular}

reliability has been given in the Table 2 .

\section{RESULTS AND DISCUSSION}

On the basis of reliability and validity results, it is believed that the instrument as a whole has valid contents. Successful KM should stem from the attention or importance placed on the necessary factors.

\section{Curriculum portal factors analysis}

The questions were included in the survey instrument that required respondents to indicate the level of importance of that factor for the inclusion in the KM system on a scale from 1 to $5(1=$ not important at all and $5=$ very Important).

A mean score was calculated for each factor to examine its level of importance. The resultant values of both group A (management, senior academia) and of group B (junior academia and research scholar) are summarised in first two columns of Table 3 . All the values ranged between 4 and 5 score for both the groups. Although, there were differences between the mean importance values perceived by the Group $A$ and by the Group B, a statistical test was needed to determine their significance. Ordinary comparison t-test was performed for this purpose to find out if the two sets of rating are "significantly different" or not. For this, there is a need to specify hypothesis which is as follows:

$\mathrm{H}_{1}$ : "There is no significant difference in the rating given to factors for the inclusion in the KM portal for curriculum development by group A (senior management and senior academia) and group B (junior academia and research scholars)".

On the basis of the result either the null hypothesis (that is, prove that group A and group B rating are significantly different) would be rejected, or would fail to reject it (conclude that there is no difference between the group $A$ and group $B$ ratings). The decision rule for the test (for any computerised output which gives a ' $p$ ' value for the test) at 0.05 significance level is that if the ' $p$ ' value is less than the significance level set up for the test, we reject the null hypothesis, otherwise, we accept the hypothesis
(Nargundkar, 2010). The results of the t-test are shown in Table 3. The t-tests revealed that in both groups, management, senior academia (thinkers) and junior academia, research scholars (doers) had no significant difference between the perceived importances of factors for the inclusion in knowledge management system. The results reflect that the importance of the all factors perceived by the "thinkers" are commonly shared and agreed by the "doers". This is considered an essential finding because a more global statement can now be made about the factors that are crucial for KM implementation.

Since there are eight factors, to systematize them for the inclusion in KM curriculum development portal, factor analysis has been performed. On the basis of factor analysis of data collected through survey the curriculum development section is further divided on the basis of three factors. These three factors explain $73.638 \%$ of variation. These are:

(a) $\mathrm{CF}_{1}$ : Curriculum design and improvisation.

(b) $\mathrm{CF}_{2:}$ Faculty development and knowledge bank.

(c) $\mathrm{CF}_{3:}$ Corporate feedback, assessment techniques (tech.) and lessons learned.

All the three factors along with their items and their loading is shown in Table 4. In case of $\mathrm{CF}_{1}$ : Curriculum design and improvisation, its first item, "curriculum revision efforts that include lesson plan, content sequencing, reference of contents and so forth" had higher item loading and higher mean score and is more important than its second item, "content modularized to facilitate interdisciplinary curriculum design and development".

The second factor $\mathrm{CF}_{2:}$ Faculty development and knowledge bank had a higher mean score than other two factors and thus is very important. In this factor, "faculty development opportunities, information related to teaching and learning with technology, outcomes tracking, technology overviews and so forth" had the highest loading and second highest mean and thus is more important than other two items.

In the third factor, $\mathrm{CF}_{3:}$ Corporate feedback, assessment techniques and lessons learned, the item, "corporate relationships to identify curriculum design advisory task forces, guest speakers, adjuncts, case study sites and so forth" had highest item loading and highest mean score than other two items. 
Table 3. Mean Score and t-test of KM portal factors.

\begin{tabular}{|c|c|c|c|c|c|}
\hline \multirow[b]{2}{*}{ KM portal factors } & \multicolumn{5}{|c|}{ t-test (equal var. assumed) } \\
\hline & $\begin{array}{l}\text { Mgmt., } \\
\text { senior } \\
\text { academia }\end{array}$ & $\begin{array}{l}\text { Junior } \\
\text { academia and } \\
\text { research } \\
\text { scholars }\end{array}$ & $\mathbf{T}$ & p (sig.) & Result \\
\hline $\begin{array}{l}\text { Curriculum revision efforts that include lesson plan, } \\
\text { content sequencing, reference of contents and so forth. }\end{array}$ & 4.60 & 4.54 & 0.623 & 0.748 & Accept \\
\hline $\begin{array}{l}\text { Content modularized and arranged to facilitate } \\
\text { interdisciplinary curriculum design and development. }\end{array}$ & 4.34 & 4.22 & 0.994 & 0.215 & Accept \\
\hline $\begin{array}{l}\text { Assessment techniques, including best practices, } \\
\text { outcomes tracking, faculty development opportunities } \\
\text { and research. }\end{array}$ & 4.56 & 4.39 & 1.319 & 0.916 & Accept \\
\hline $\begin{array}{l}\text { Analyzed student evaluations updated each semester for } \\
\text { lessons learned and best practices for all faculty. }\end{array}$ & 4.51 & 4.36 & 1.146 & 0.541 & Accept \\
\hline $\begin{array}{l}\text { Corporate relationships to identify curriculum design } \\
\text { advisory task forces, guest speakers, adjuncts, case } \\
\text { study sites and so forth. }\end{array}$ & 4.56 & 4.41 & 1.071 & 0.463 & Accept \\
\hline $\begin{array}{l}\text { Information related to teaching and learning with } \\
\text { technology including faculty development opportunities, } \\
\text { outcomes tracking, technology overviews, and so forth. }\end{array}$ & 4.58 & 4.53 & 0.467 & 0.988 & Accept \\
\hline $\begin{array}{l}\text { Information in each disciplinary area, including updated } \\
\text { materials, recent publications, applicable research, and } \\
\text { so forth. }\end{array}$ & 4.60 & 4.55 & 0.515 & 0.620 & Accept \\
\hline $\begin{array}{l}\text { New faculty with guides for developing curriculum, } \\
\text { working with senior faculty, establishing effective } \\
\text { teaching styles, advising do's and do not's, supervising } \\
\text { PhD students and so forth. }\end{array}$ & 4.36 & 4.41 & -0.300 & 0.885 & Accept \\
\hline
\end{tabular}

\section{KNOWLEDGE MANAGEMENT PORTAL FRAMEWORK FOR CURRICULUM DEVELOPMENT}

"Know where to find the information and how to use it that's the secret of success". - Albert Einstein.

Bernbom (2001) explains that KM involves the "discovery and capture of knowledge, the filtering and arrangement of this knowledge and the value derived from sharing and using this knowledge throughout the organization". It is this "organized complexity" of collaborative work to share and use information across all aspects of an institution which marks the effective use of knowledge. According to Thorn (2001), the problem is that it is such a "wide open area of study that it is difficult to understand the implications of knowledge management for an educational setting". An organizational knowledge management portal can facilitate information delivery to the right person at the right time and create a virtual environment where individuals can collaborate, communicate, conduct research and plan activities based on common interest. "The portal is the interface, the place where information exchange and knowledge transfer takes place, but it is only one component of successful KM" (Cloete and Snyman, 2003).

On the basis of inputs given by the academia, it is possible to construct highly usable and intuitive interfaces which can facilitate generation of intellectual capital, knowledge sharing and reuse of knowledge assets. It may be used to create a blueprint-for developing a knowledge management portal for higher educational institutions.

The academia can access the knowledge from the portal in a systematic and convenient way without wasting their energy and time. The portal internally retrieves the information from repository and provides it to the portal user. All the three factors are incorporated in the framework. Collaboration tools are also added since 
Table 4. Factors for implementing KM portal for curriculum development.

\begin{tabular}{|c|c|c|c|c|c|c|c|}
\hline $\begin{array}{l}\text { Factor } \\
\text { no }\end{array}$ & Factor name & $\begin{array}{l}\text { Eigen } \\
\text { value }\end{array}$ & $\begin{array}{c}\% \text { of } \\
\text { var. exp. }\end{array}$ & Items & $\begin{array}{l}\text { Item } \\
\text { loading }\end{array}$ & Mean & S.d. \\
\hline \multirow[b]{2}{*}{1} & \multirow{2}{*}{$\begin{array}{lr}\mathrm{CF}_{1}: & \text { Curriculum } \\
\text { design } & \text { and } \\
\text { improvisation } & \end{array}$} & \multirow[b]{2}{*}{2.526} & \multirow[b]{2}{*}{31.574} & $\begin{array}{l}\text { i. Curriculum revision efforts that } \\
\text { include lesson plan, content } \\
\text { sequencing, reference of contents } \\
\text { and so forth. }\end{array}$ & 0.889 & 4.56 & 0.60 \\
\hline & & & & $\begin{array}{l}\text { ii. Content modularized and } \\
\text { arranged to facilitate } \\
\text { interdisciplinary curriculum design } \\
\text { and development. }\end{array}$ & 0.729 & 4.25 & 0.65 \\
\hline \multirow{2}{*}{\multicolumn{4}{|c|}{ Mean score of curriculum design and improvisation }} & & & 4.40 & \\
\hline & & & & $\begin{array}{l}\text { i. Faculty development } \\
\text { opportunities, information related } \\
\text { to teaching and learning with } \\
\text { technology, outcomes tracking, } \\
\text { technology overviews, and so } \\
\text { forth. }\end{array}$ & 0.801 & 4.54 & 0.63 \\
\hline \multirow[t]{2}{*}{2} & \multirow[t]{2}{*}{$\begin{array}{l}\mathrm{CF}_{2}: \quad \text { Faculty } \\
\text { development and } \\
\text { Knowledge bank }\end{array}$} & \multirow[t]{2}{*}{1.781} & \multirow[t]{2}{*}{22.264} & $\begin{array}{l}\text { ii. Information in each disciplinary } \\
\text { area, including updated materials, } \\
\text { recent publications, applicable } \\
\text { research, and so forth. }\end{array}$ & 0.778 & 4.56 & 0.62 \\
\hline & & & & $\begin{array}{l}\text { iii. New faculty with guides for } \\
\text { developing curriculum, working } \\
\text { with senior faculty, establishing } \\
\text { effective teaching styles, advising } \\
\text { do's and do not's, supervising } \\
\text { PhD students and so forth. }\end{array}$ & 0.731 & 4.39 & 0.79 \\
\hline \multicolumn{5}{|c|}{ Mean score of faculty development and knowledge bank } & & 4.50 & \\
\hline \multirow{3}{*}{3.} & \multirow{3}{*}{$\begin{array}{l}\mathrm{CF}_{3}: \text { Corporate } \\
\text { feedback, } \\
\text { assessment } \\
\text { techniques and } \\
\text { lessons learned }\end{array}$} & \multirow{3}{*}{1.584} & \multirow{3}{*}{19.800} & $\begin{array}{l}\text { i. Assessment techniques, } \\
\text { including best practices, outcomes } \\
\text { tracking and research. }\end{array}$ & 0.706 & 4.43 & 0.70 \\
\hline & & & & $\begin{array}{l}\text { ii. Analyzed student evaluations } \\
\text { updated each semester for } \\
\text { lessons learned and best } \\
\text { practices for all faculty. }\end{array}$ & 0.772 & 4.40 & 0.71 \\
\hline & & & & $\begin{array}{l}\text { iii. Corporate relationships to } \\
\text { identify curriculum design advisory } \\
\text { task forces, guest speakers, } \\
\text { adjuncts, case study sites and so } \\
\text { forth. }\end{array}$ & 0.837 & 4.45 & 0.76 \\
\hline \multirow{2}{*}{\multicolumn{6}{|c|}{$\begin{array}{l}\text { Mean score of corporate feedback, assessment techniques and lessons learned } \\
\text { Mean score of all factors }\end{array}$}} & 4.43 & \\
\hline & & & & & & 4.44 & \\
\hline
\end{tabular}

in interviews, authors found out that either the academia was hesitant to go personally to ask for information from someone or they did not know whom to approach. This problem can be solved by initiating discussion forums using collaboration tools in KM portal (Figure 3).

\section{First factor: Curriculum design and improvisation}

The first factor viz. Curriculum design and Improvisation has the two items: i) curriculum revision efforts that include lesson plan, content sequencing, reference of 


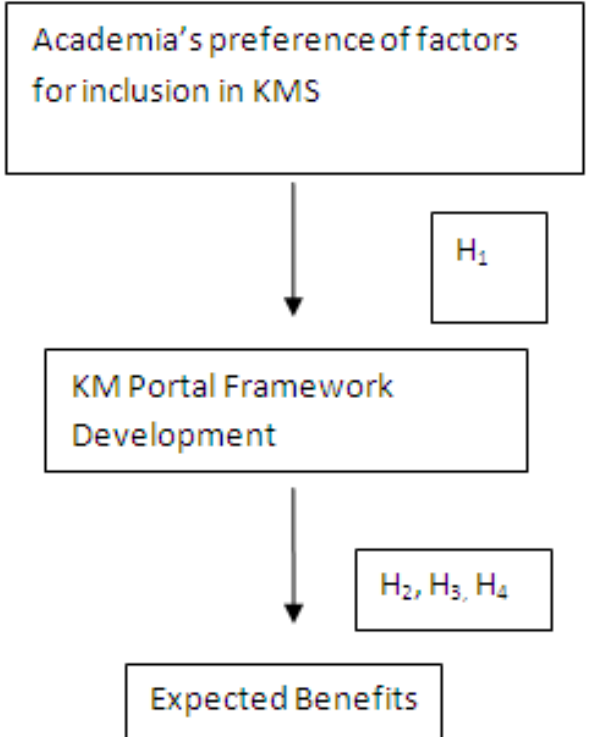

Figure 3. Design of research.

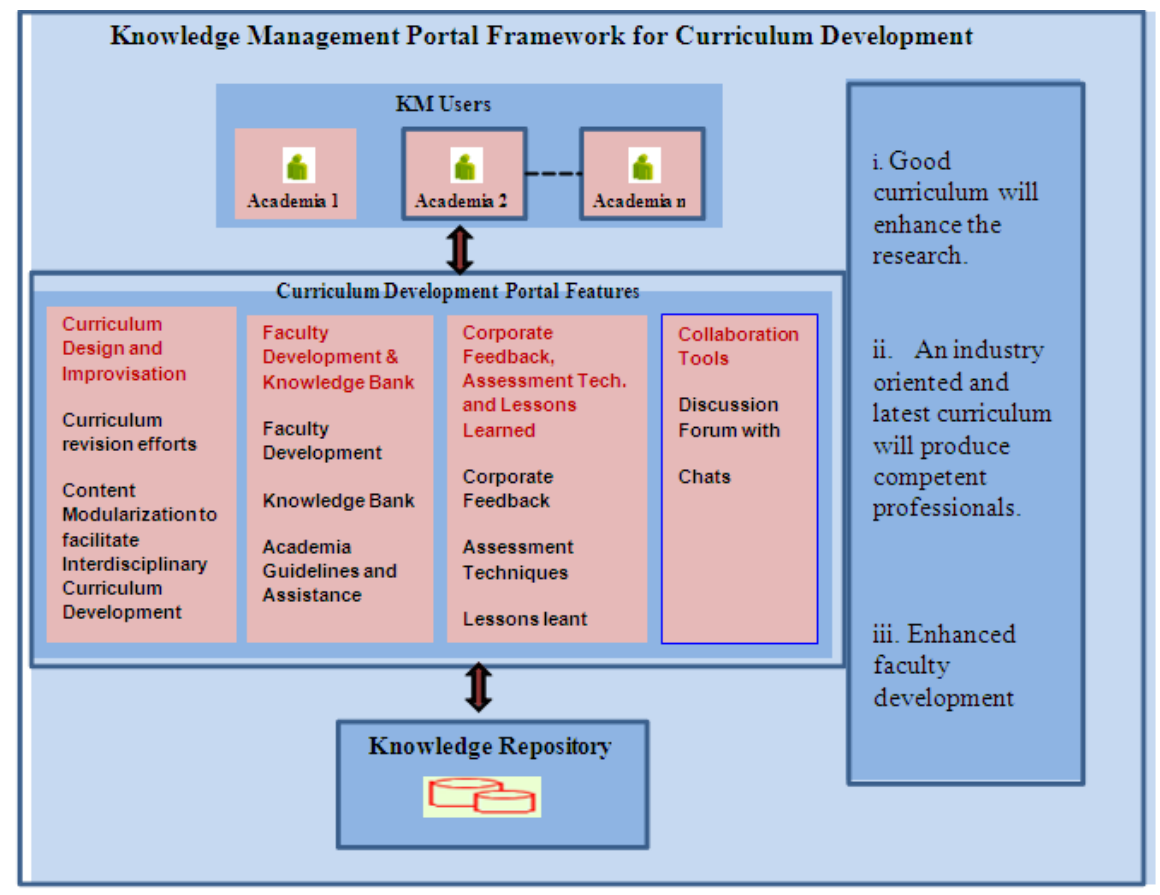

Figure 4. Knowledge management portal framework for curriculum development.

contents and so forth; and ii) content modularization to design interdisciplinary curriculum and development. This factor explains $34.51 \%$ of total variation (Figure 4 ).

\section{Curriculum revision efforts}

This variable is more important as it has higher item loading as well as higher mean score. Learning should always be planned and guided. The educator should always plan in advance what he/she is seeking to achieve and how to achieve it. To facilitate the academia in devising the curriculum, the template of design and guidelines are provided and also previous lesson plans can be provided for the reference for the following five sections in the portal as shown in web shot1 (Figure 5 


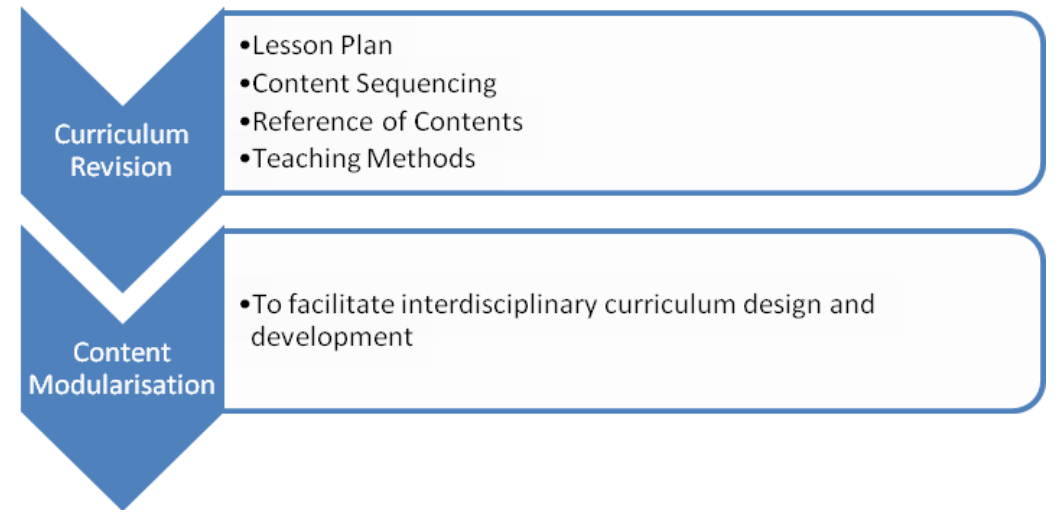

Figure 5. Items of first factor: curriculum design and improvisation.
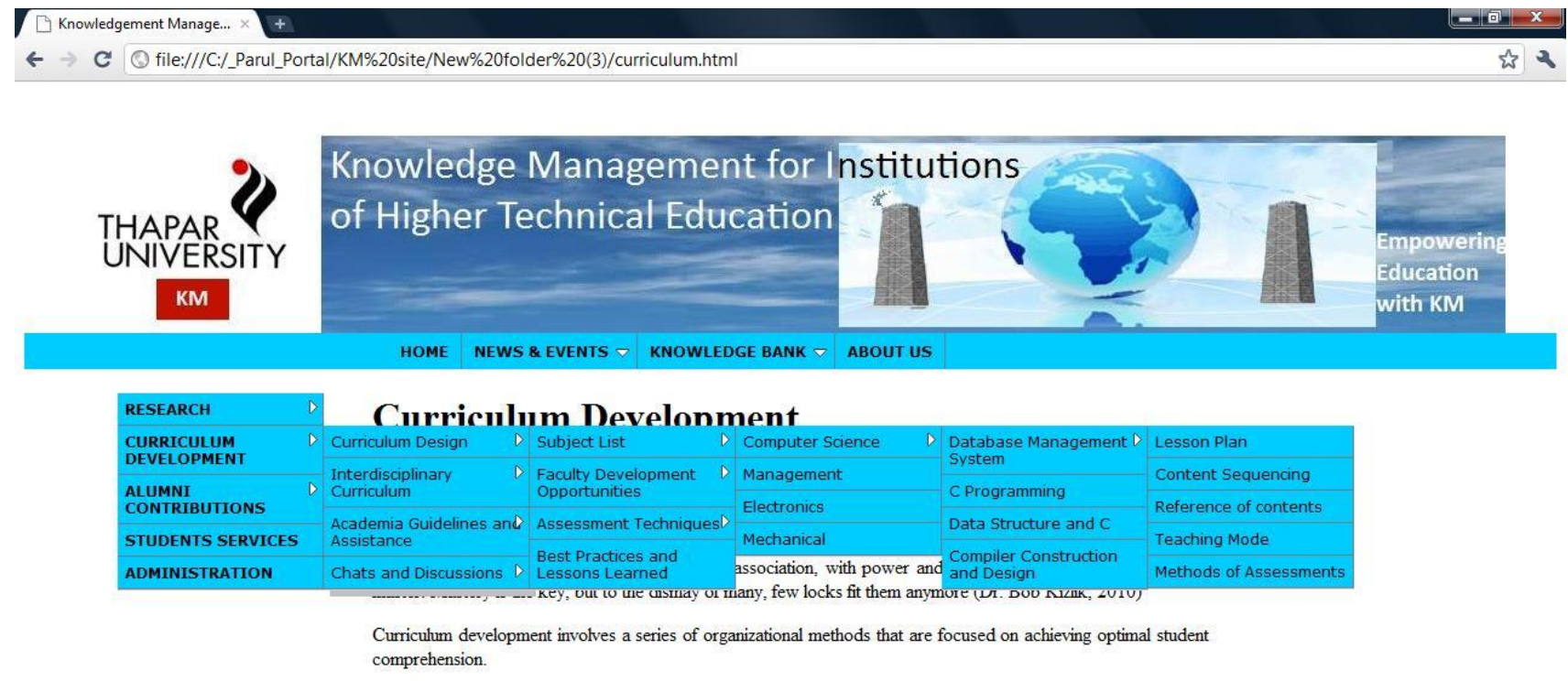

file////C:_Parul_Porta//KM site/New folder (3)/Curriculum.htm|\#

Figure 6. Web shot 1: Curriculum design.

and 6).

Lesson plan: The educator outlines the course and kind of goals are addressed in the course.

Content sequencing: The educator should determinethe scope and sequence of the content in advance to improvise the dissemination of knowledge.

Reference of contents: All the instructions and help required by the educator to find the references are provided.

Teaching method: There are various kinds of teaching methods which can be used by the educators like lecture, lecture with discussion, brainstorming, videotapes, class discussion, small group discussion, case study, laboratory/practical classes, role playing, problem based learning, and worksheet/assignment. Their way of implementation, pros and cons are explained in this section. An educator can plan his/her curriculum more efficiently and systematically by using this section of the portal. 

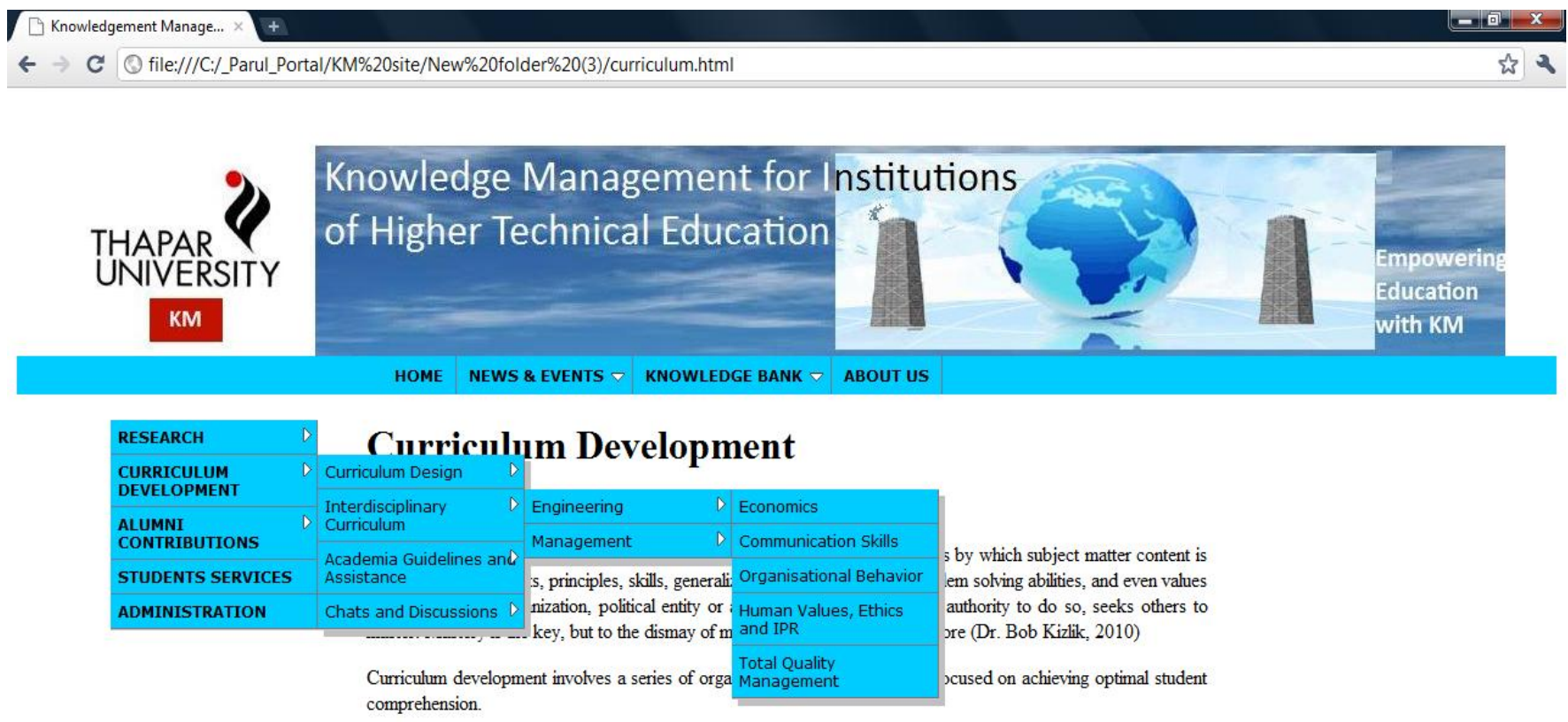

$\underline{\text { About Us }}|\underline{\text { Site Map }}| \underline{\text { Privacy Policy }} \mid$ Contact Us $\mid$ @2010 RAP Associates

\section{file///CC/_Parul_Portal/KM site//New folder (3)/Curiculum.htm|*}

Figure 7. Web shot 2: Interdisciplinary curriculum.

\section{Content modularized to facilitate interdisciplinary curriculum design and development}

Interdisciplinary curriculum is becoming very important in today's world. Writing in the chronicle of higher education, Wasserstrom (2006) complains that interdisciplinarity has become "so fuzzy that a university's commitment to it is close to meaningless". If programs claiming to be interdisciplinary are fuzzy in their understanding of what inter-disciplinarity is, then their curriculum will not provide the proven educational outcomes for students that inter-disciplinarity promise. This, in turn, will severely compromise meaningful assessment of these programs. Klein (1999) argues in mapping interdisciplinary studies that interdisciplinary curriculum must make sense locally and yet, to achieve quality, also ought to be informed by research and the national conversation. Designing interdisciplinary curriculum, therefore, requires familiarity with the extensive literature on inter-disciplinarity. Academia can be facilitated with the same through this section. They can share their ideas of interdisciplinary curriculum with other educators through KM portal as shown in the screenshot (Figure 7). After selecting the interdisciplinary curriculum, the academia can further select the subject after selecting its department. On the displayed page, the IHTE can share its detailed information regarding the scope of inter-disciplinarity of the particular subject.

\section{Second factor: Faculty development and knowledge bank}

Faculty development has become an increasingly prominent concept for a growing number of faculties. It is essential that a faculty development program should be both comprehensive and also based on a set of diverse, though related strategies to bring about the significant improvements in instruction demanded by the new and difficult issues facing higher education. Here, we present a brief overview of faculty development, both the organizational as well as personal development (Figure 8). This factor has the following items, viz. i) faculty development opportunities, information related to teaching and learning with technology, outcomes tracking, technology overviews, and so forth; ii) information in each disciplinary area, including updated materials, recent publications, applicable research and so forth; iii) new faculty with guides for developing curriculum, working with senior faculty, establishing effective teaching styles, advising 


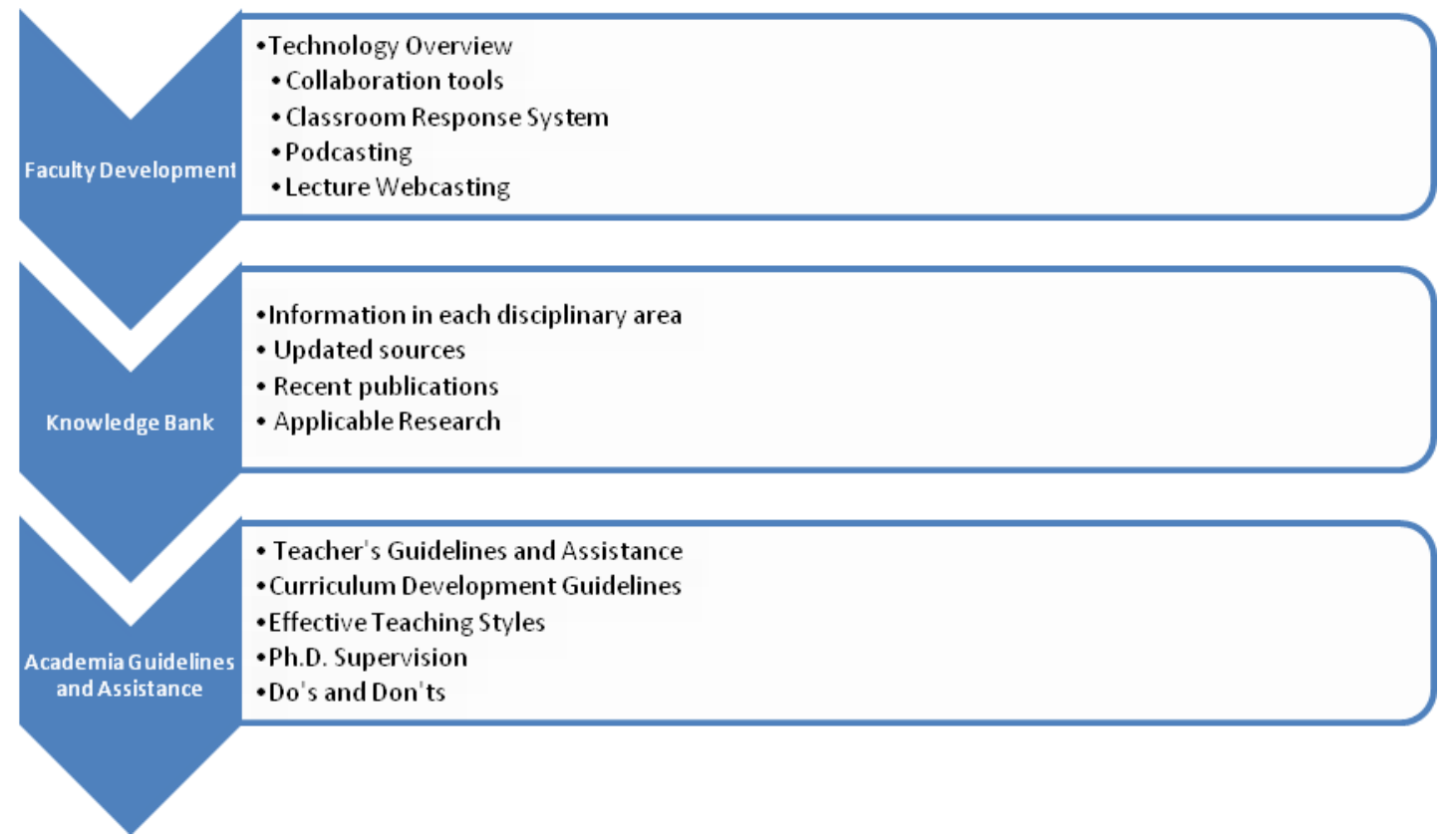

Figure 8. Items of second factor: Faculty development and knowledge bank.
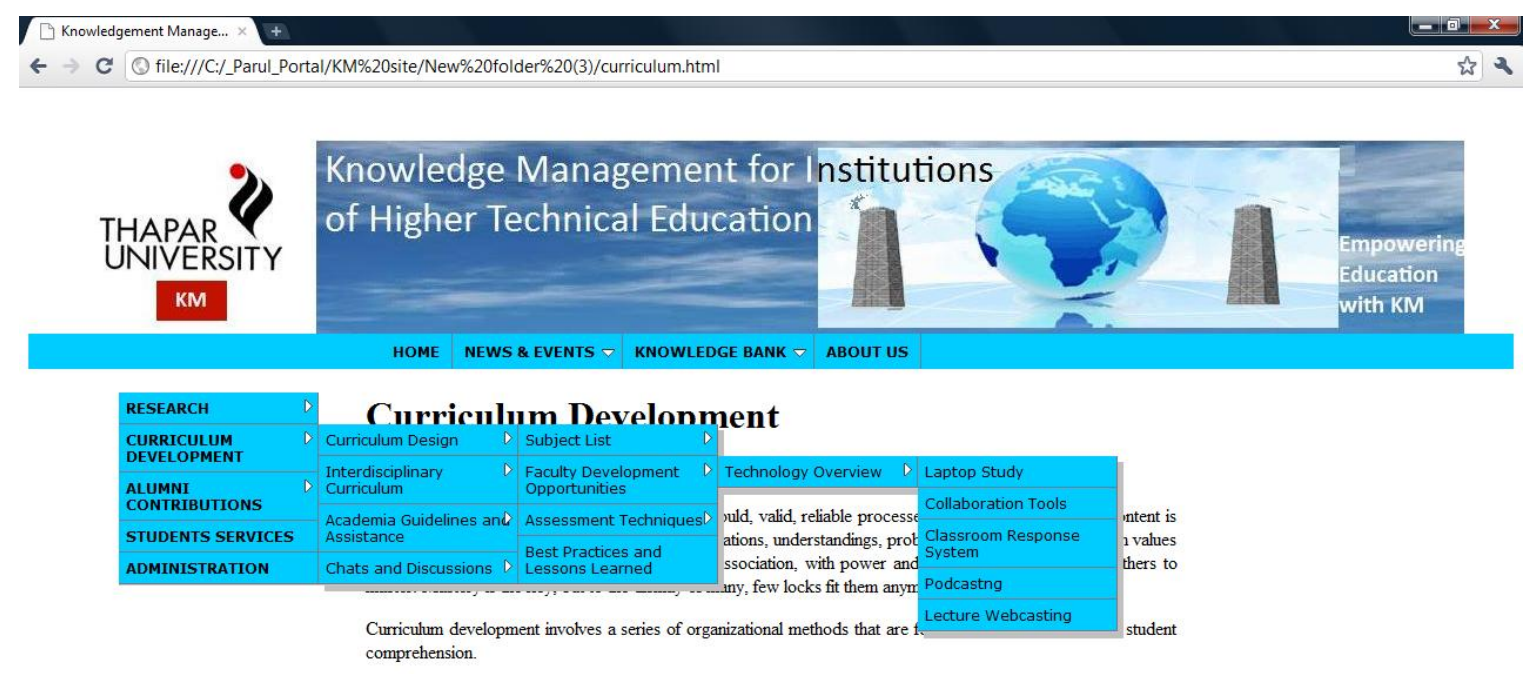

About Us $|\underline{\text { Site Map }}|$ Privacy Policy $\mid$ Contact Us $\mid$ @2010 RAP Associates

\section{File///C:_/_Parul_Porta//KM site/New folder (3)/curriculum.hthm|"}

Figure 9. Web shot 3: faculty development opportunities.

“do's and do not's, supervising PhD students and so forth (Figure 9).

From these three variables: i) faculty development opportunities, information related to teaching and learning with technology, outcomes tracking, technology overviews, and so forth, ii) information in each disciplinary area, including updated materials, recent publications, applicable research, and so forth, are more important and have higher loading than the last variable viz., iii) new faculty with guides for developing curriculum, working with senior faculty, establishing effective teaching styles, advising "do's and do not's", supervising PhD students 
and so forth as well as higher mean score.

\section{Faculty development}

Technology overview: Educators can benefit from a more detailed view of available tools and how they can be used more effectively in support of specific teaching and learning goals. Educators can be exposed to the evolving methods of teaching and learning like:

(i) Laptop study

(ii) Collaboration tools

(iii) Classroom response systems

(iv) Podcasting

(v) Lecture webcasting

Academia can update its knowledge regarding technological developments in the educational sector by clicking "technology overview" in "faculty development opportunities" and further can explore desired listed technologies.

\section{Knowledge bank}

It is important for the higher institutions to "know what they know" and to make maximum use of that knowledge. This knowledge resides in many different parts of the institution and often one part of an institution repeats the same work in another part simply because it is impossible to keep track of and make use of, knowledge in other parts. Enterprises need to know, what their knowledge assets are; and how to manage and make use of these assets to get maximum return. To accomplish this, the following sections are made in the portal under knowledge bank:

(i) Information in each disciplinary area

(ii) Updated sources

(iii) Recent publications

(iv) Applicable research

\section{Academia guidelines and assistance}

Every institute has its own set of rules, guidelines and recommendations which can be elucidated in this segment with the following subdivisions:

Teacher's guidelines and assistance: This defines the roles and responsibilities of the educator. These guidelines will provide direction to educators to deliver his/her best to stakeholders.

Curriculum development guidelines: These guidelines are a list of suggestions for the development of curriculum. It may also explain the items such as manuals, handbooks, computer programs, audiovisual aids, etc. Depending on the medium and the number of students involved in the project or class under consideration, these guidelines can be adjusted or supplemented.

Effective teaching styles: An effective teaching methodology aims at creating a dynamic learning environment and engaging the attention of the students toward what is being taught. It also fosters interaction among the students and develops reciprocity.

PhD. supervision: The different scenarios and styles on supervision which are accepted by the particular IHTE can be provided. It can offer strategies for dealing with some of the challenges and provides guidelines for $\mathrm{PhD}$ supervision and mentoring. A valuable insight into best practice models for $\mathrm{PhD}$ supervision and mentoring, appropriate to the context of particular higher educational institution can contribute to the development of the next generation of researchers and academics who are key to vibrating research and innovating system.

Do's and do not's: The management of HEI can notify its rule in this part like what is expected from the academia and what is not.

The detailed information about the IHTE's rules can be gained by visiting this section and also an educator can get the assistance.

Every higher educational institution has its own rules and guidelines which it can list under the section "academia guidelines and assistance" as shown in Figure 10.

\section{Third factor: Corporate feedback, assessment techniques and lessons learned}

The next factor viz. "Corporate feedback, assessment techniques and lessons learned" covers the following variables:

(i) Assessment techniques, including best practices, outcomes tracking and research.

(ii) Analyzed student evaluations updated each semester for lessons learned and best practices for all faculty.

(iii) Corporate relationships to identify curriculum design advisory task forces, guest speakers, adjuncts, case study sites and so forth as depicted in Figure 8.

In this factor the third variable viz. corporate relationships to identify curriculum design advisory task forces, guest speakers, adjuncts, case study sites and so forth had highest item loading and mean score. The educators can share their experiences and knowledge and can also learn from others experiences with knowledge imparted here.

\section{Corporate feedback}

To keep the pace with the ever changing demands from 
$\square$ Knowledgement Manage... $\times$

$\leftarrow \rightarrow$ C O file:///C:/_Parul_Portal/KM\%20site/New\%20folder\%20(3)/curriculum.html

\section{Knowledge Management for Institutions} of Higher Technical Education

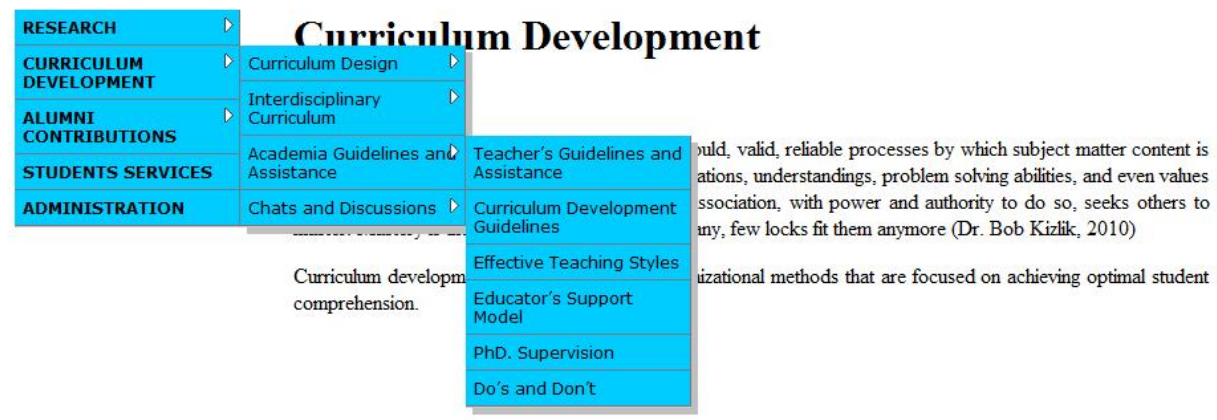

$\underline{\text { About Us }}|\underline{\text { Site Map }}| \underline{\text { Privacy Policy }} \mid \underline{\text { Contact Us }}$ | 2010 RAP Associates

\section{file///C//_Parul_Porta//KM site/New folder (3)/_curriculum.htm|\#}

Figure 10. Web shot 4: Academia guidelines and assistance.

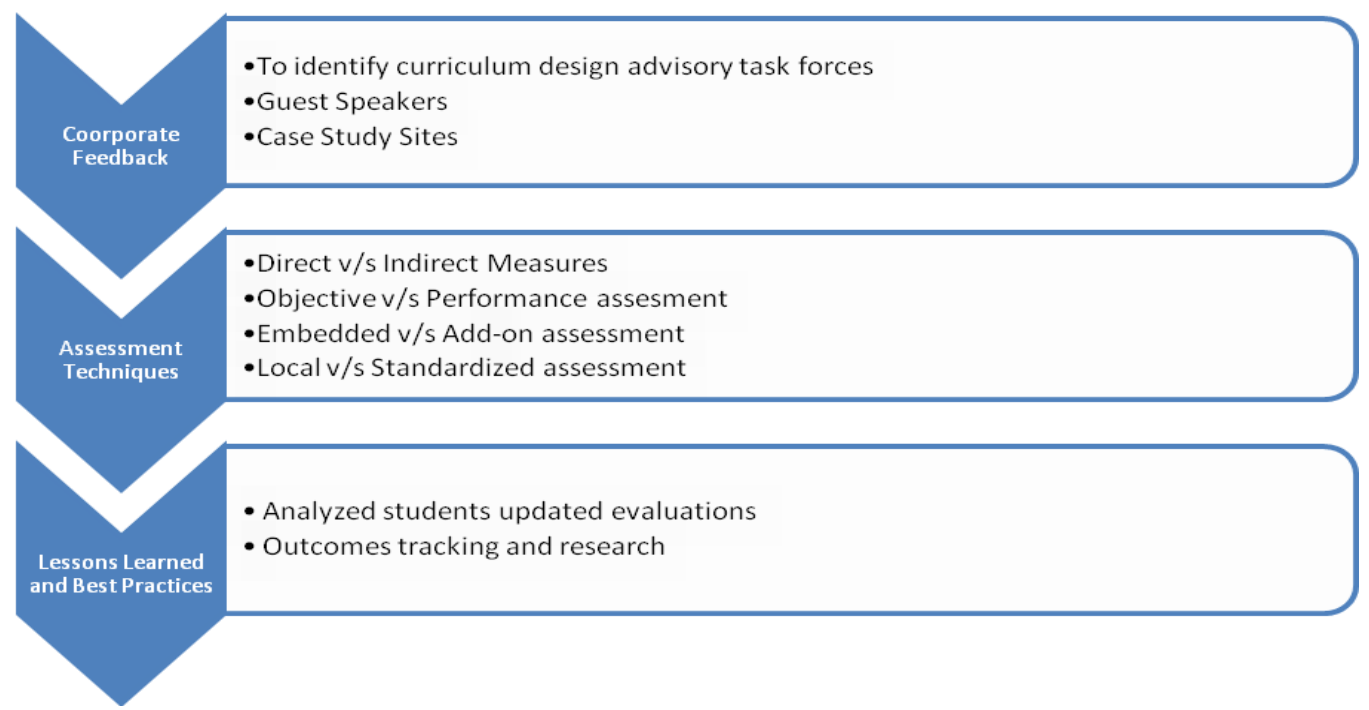

Figure 11. Items of third factor: Corporate feedback, assessment techniques, lessons learned.

the industry, there is a need for the higher educational institutions to offer stakeholder that is learners to offer effective learning environment, state-of-art research, dynamic and industry oriented curriculum, which can place them above par (Figure 11). To incorporate the feedback from the corporate sector following section has been added in the portal with following options:

(i) To identify design advisory task force

(ii) Guest speakers 

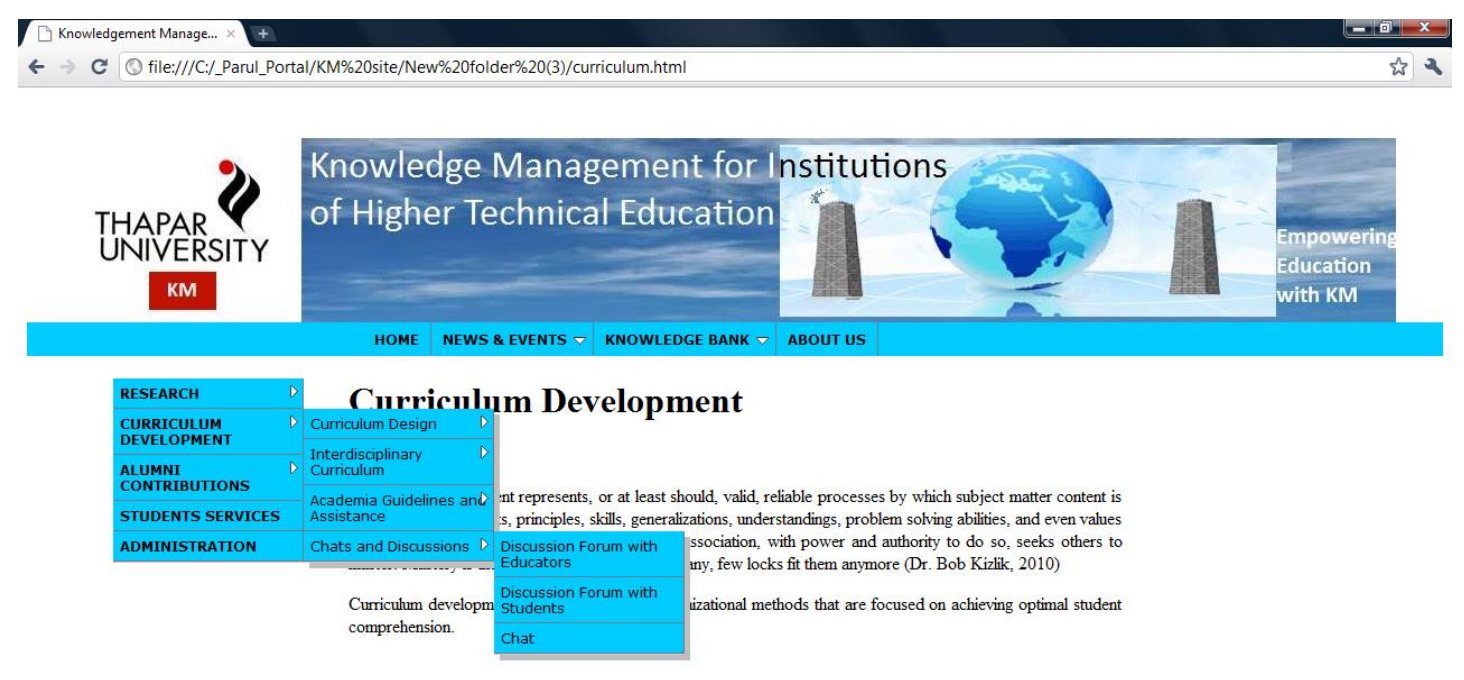

About Us $\mid$ Site Map $\mid$ Privacy Policy $\mid$ Contact Us $\mid$ @2010 RAP Associates

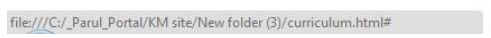

Figure 12. Web shot 5: Chats and discussions.

(iii) Case study sites

\section{Methods of assessments}

Selecting appropriate means for assessment is an essential step in assessment process. There are many different ways to assess the learning of the student:

(i) Direct versus indirect measures

(ii) Objective versus performance assessment

(iii) Embedded versus add-on assessment

(iv) Local versus standardized assessment

By taking into account the number of learners and considering the nature of the subject, the educator should decide the method of assessment. Different prospects and guidelines about assessment methods are given here.

\section{Lessons learned and best practices}

The educators can share their experiences and knowledge and can also learn from others experiences with knowledge imparted in this part by having following subsections:

(i) Analyzed students updated evaluations

(ii) Outcomes tracking and research

\section{Collaboration tools}

From the personal interviews, the authors had realized that there is a need of collaboration tools in IHTE as explained earlier. Collaboration tools are provided in this section. Academia can discuss the issues among each other or with learners. This part has been divided into three parts as shown subsequently:

\section{Discussion forum with educators}

If any educator wants some suggestion on any issue or wants to discuss about new methodology, assessment techniques etc. among other educators then he can start a new topic on this discussion forum.

\section{Discussion forum with students}

If the educator wants to take feedback or wants to discuss about new teaching methodology or new ideas with students then this could be the best platform which gives the chance to express its view without any pressure.

\section{Chat}

It is a form of instant communication over the internet. It is mainly designed for group (one-to-many) communication in discussion forums called channels, but also allows one-to-one communication.

The layout of all the options is shown in the web shot in Figure 12.

This knowledge can be shared with educator through 
Table 5: Regression Results.

\begin{tabular}{|c|c|c|c|c|c|}
\hline Variable & $B$ & SE B & $\beta$ & $T$ & $\mathbf{P}$ \\
\hline (Constant) & 1.027 & 0.265 & & 3.874 & $0.001^{* *}$ \\
\hline $\begin{array}{l}\text { Curriculum Design and Improvisation } \\
\text { (CF1) }\end{array}$ & 0.41 & 0.065 & 0.418 & 6.305 & $0.001^{* *}$ \\
\hline $\begin{array}{l}\text { Faculty Development and Knowledge } \\
\text { bank (CF2) }\end{array}$ & 0.349 & 0.053 & 0.434 & 6.535 & $0.001^{* *}$ \\
\hline $\begin{array}{l}\text { Corporate Feedback, Assessment } \\
\text { Techniques and Lessons Learned } \\
\text { (CF3) }\end{array}$ & 0.004 & 0.061 & 0.006 & 0.057 & 0.954 \\
\hline
\end{tabular}

Notes: $R=0.738 ; R^{2}=0.544 ;$ Adjusted $R^{2}=0.538 ; \quad S$. E of Regression= .38; $D W=1.54$

F-statistics $=82.473, p<0.001$

CF3: Excluded variable

${ }^{* *}$ significant at .01 percent

portal as shown in the screenshot (Figure 12). Educator can get more information about the innovative tools for teaching by selecting the option of his/her interest.

\section{RELATIONSHIP BETWEEN PERCEIVED BENEFITS AND KM PORTAL FOR CURRICULUM DEVELOPMENT}

According to Kidwell et al. (2001), the KM portal will improve the efficiency of knowledge exchange and deliver a set of shared business objectives that include communications around best practices, a gateway to research on the use of teaching and learning through technology, professional development, policy development and review, and resource development. The portal provides the faculty members at the individual campuses with efficient, direct links to current knowledge about teaching and learning through technology among the campuses of the university system, nationally and internationally.

Thus the next part of the survey is related to finding out through regression analysis from the academia the areas of education that will benefit the most with the implementation of KM portal. The dependent variables of the study are perceived benefits of KM portal for curriculum development. This has the following items viz:

(i) Good curriculum will enhance the research.

(ii) An industry oriented and latest curriculum will produce competent professionals.

(iii) Enhanced faculty development efforts.

The independent variables of the study are the three factors as identified by faculty for portal analysis. These are:

$\mathrm{CF}_{1}$ : Curriculum design and improvisation

$\mathrm{CF}_{2}$ : Faculty development and knowledge bank
$\mathrm{CF}_{3}$ : Corporate feedback, assessment techniques and lessons learned.

The details of these have been explained earlier. Regression results are depicted in Table 5 . The results of step-wise regression depicts that $R$ is 0.738 and $R^{2}$ is 0.544. The predictors of model are: i) $\mathrm{CF}_{1}$ : Curriculum design and improvisation; and ii) $\mathrm{CF}_{2}$ : Faculty development and knowledge bank. The value of $\mathrm{F}$ statistics is 82.473 and is significant $(p<0.001)$, depicting that the model is good.

The second hypothesis $\mathrm{H} 2$ is that the perceived benefits that emerge from development of a curriculum development portal may be positively related with curriculum design and improvisation. Here the value of $B$ for CF1: Curriculum design and improvisation is highest. The value of $t$ is also significant and it is positively related with perceived benefits of curriculum development. Hence this hypothesis has been accepted.

The third hypothesis $\mathrm{H}_{3}$ is that the perceived benefits that emerge from development of a curriculum development portal may be positively related with faculty development and knowledge bank is also accepted as seen from results. But at the same time, it must be mentioned that the value of $\mathrm{B}$ for $\mathrm{CF}_{2}$ : Faculty development and knowledge bank is low but $t$ value is significant hence it has been accepted. The third factor viz. Corporate Feedback, Assessment Techniques and Lessons Learned (CF3) though positively related with perceived benefits hasn't emerged as important predictor for the model.

\section{CONCLUSIONS}

The growth in the number of internet users has given an added impetus to globalization. Information patterns have transformed the electronic information systems by the use of cyber technologies. As a result of this, knowledge 
transmission patterns within academic organizations must develop and change the education systems in order for information to be effectively transmitted. Consequently, knowledge management method is becoming a perfect education development tool for all academic levels (Thitithananon and Klaewthanong, 2007). The academia has responded that they support the implementation of KM technologies and ICT for KM portal for curriculum development.

According to Brown and Duguid (2000), profound changes in competition have made universities and higher education institutions think like business. The educational markets are becoming global as universities attempt to internationalise their curricula and offer high quality programs to students regardless of location. To excel IHTE should have state-of-the-art and industry oriented curriculum which can be achieved by meticulous efforts by creating and sharing knowledge which can be attained with the help of knowledge management by using web based technologies. The academia has voted for all the factors for the inclusion in the KM portal.

The perceived benefits that emerge from development of a curriculum development portal are positively related with curriculum design and improvisation, faculty development opportunities and best practices and lessons learned. Regression results also highlight $\mathrm{CF}_{1}$ : Curriculum design and improvisation and ii) $\mathrm{CF}_{2}$ : Faculty development opportunities as important predictors of the model. To remain ahead in the competition even well established IHTE has to respond to the challenge by offering learners dynamic and industry oriented curriculum. To achieve this there is need to facilitate academia with technology driven knowledge management based platform which can help them to design innovative, industry oriented, and state-of -art curriculum. The portal for curriculum design will help IHTE to adjust them and develop strategies to respond rapidly to the changes in technologies and increasing demands of stakeholders.

\section{REFERENCES}

Alberthal L (1995). Remarks to the Financial Executives Institute. Dallas. TX.

Alvesson M, Karreman D (2001). Odd Couple: Making Sense of the Curious Concept of Knowledge Mangement. J. Manag. Stud. 38(7) :995-1018.

Bateson G (1988). Mind and Nature: A Necessary Unity. New York: Bantam Books.

Bernbom G (2001). Information Alchemy: The Art and Science of Knowledge Management. San Francisco Jossey - Bass: EDUCAUSE Leadership Series \#3.

Bohn RE (1994). Measuring and managing technological knowledge. Sloan Manage. Rev. 26(1):61-73.

Brown JS, Duguid P (2000). The Social Life of Information. Boston: Harvard Business School Press.

Chauvel D, Despres C (2002). A review of survey research in knowledge management. J. Know. Manag. 6(3):207-23.

Cloete M, Snyman R (2003). The enterprise portal - is it knowledge management? Aslib Proceedings: new information persp. 55(4) :234242.
Coukos E (2003). Knowledge Management in Research Universities: The Process and Strategies. Paper presented at the Annual Meeting of the American Educational Reserach Association,Chicago, IL. p.57.

Davenport T, Prusak L (1998). Working Knowledge. Boston: MA: Harvard Business School Press.

Drucker P (1993). Post-Capitalist Society. New York: Harper Business.

Foray D, Lundvall BD (1996). The knowledge-based economy. from the economics of knowledge to the learning economy, in: Employment and growth in the knowledge-based economy :11-32 Paris:OECD.

Jarrar Y (2002). Knowledge management: learning for organisational experience. Manag. Audit. J. 17(6):322-328.

Johnston R, Rolf B (1998). Knowledge moves to centre stage. Sci. Commun. 20(1):99-105.

Kidwell JJ, Vander Linde KM, Johnson SL (2001). Applying corporate Knowledge Management practices in higher education. In G. Bernbom, Information Alchemy: The Art and Science of Knowledge Manage. San Francisco: Jossey-Bass: pp.1-24.

Klein JT (1999). Mapping interdisciplinary studies: the academy in transition. Washington, DC: Association of American Colleges and Universities.

Kogut B, Zander U (1992). Knowledge of the firm combinative capabilities and the replication of technology. Org. Sci. 3(3):383-397.

Markus B (2002). Global spatial knowledge management. GSDI 6 Conference - From global to local. Budapest, Hungary.

McManus D, Loughridge B (2002). Corporate information, institutional culture and knowledge management: a UK university library perspective. New Lib. World 103(9):320-327.

Milam JH (2001). Knowledge Management for Higher Education. ERIC Digest, The Educational Resources Information Centre.

Miller W (1999). Flash of Brilliance - Inspiring Creativity Where You Work. MA: Perseus Books, Reading.

Nargundkar R (2010). Marketing Research. New York: Tata McGraw Hill.

Nunally J (1978). Psychometric Theory. New York, NY: McGraw-Hill.

Petrides L, Nodine T (2003). Knowledge Management In Education: Defining The Landscape. ISKME Monograph.

Richards J (2001). Curriculum development in language teaching Cambridge: Cambridge University Press.

Sharma $P$ (2007). Technical Education in Knowledge age. Univ. News, 45(26):8-11.

Skyrme D, Amidon DA (1997). Creating the knowledge-based business. Wimbledon: Business Intelligence.

Slaughter S, Leslie LL (1997). Academic Capitalism: Politics, Policies, and the Enterpreneurial University. 2715 North Charles Street Baltimore, MD 21218-4319: The Johns Hopkins University Press.

Slaughter S, Rhoades G (2004). Academic capitalism and the new economy: markets, state, and higher education. Baltimore, MD: JHU Press.

Snowden D (1999). The Paradox of Story: Simplicity Complex. Strateg., $1(5): 16-20$

Teece D (2000). Strategies for managing knowledge assets. the role of firm structure and industrial context, Long Ran. Plan., 33(1): 35-54.

Thitithananon P, Klaewthanong T (2007). Knowledge Management Is A Perfect Education Development Tool: Is Thailand's Higher Education Really Ready To Embrace It? J. Knowl. Manag. Pract. 8(2), available at http://www.tlainc.com/articl230A.htm (accessed 1 July 2011).

Thorn CA (2001). Knowledge Management for Educational Information Systems: What Is the State of the Field? Educ. Policy Anal. Arch. 9(47).

Wallacea DP, Fleetb CV, Downsc LJ (2011). The research core of the knowledge management literature. Int. J. Inform. Manag. 31(1):14-20.

Wasserstrom JN (2006). Expanding on the I-Word. Chron. High. Edu. 52(20):B5.

Wiles J, Bondi J (2006). Curriculum development - A guide to practice. New York: Merril Publishing Co.

Wiig KM, deHoog R, Vander Spek R (1997). Supporting knowledge management: a selection of methods and techniques. Expert Syst. Appl. 13(1):15-27. 